\title{
Diet and prostate cancer prevention
}

\author{
James R. Marshall \\ Roswell Park Cancer Institute, Elm and Carlton Streets, Buffalo, NY 14263, USA \\ James R. Marshall: james.marshall@roswellpark.org
}

\section{Abstract}

Purpose-To evaluate the present human-based evidence that diet is related to the risk and outcome of prostate cancer.

Methods-Review of major case-control and cohort studies, and experimental trials evaluating the effect of diet or dietary constituents on the risk of prostate cancer.

Results-Although non-experimental studies have suggested several dimensions of diet and several dietary components as related to risk and outcome of prostate cancer, the results of these studies are inconsistent. There is limited evidence that a diet that emphasizes plant products is associated with diminished risk of prostate cancer and of aggressive prostate cancer.

Conclusion-The non-experimental epidemiologic evidence that has now accrued justifies trials of dietary intervention for those at elevated risk of prostate cancer.

\section{Keywords}

Diet; Nutrition; Epidemiology; Chemoprevention; Prevention

\section{Introduction}

Prostate cancer mortality varies substantially among regions of the world; it also varies according to the socioeconomic development of these regions. The highly developed, industrialized, and affluent countries of Europe and the United States tend to have higher incidence and mortality than the developing countries [1]. Age-adjusted rates of prostate cancer incidence in Western Europe and North America range between 80 and 100 per 100,000 per year, while age-adjusted mortality ranges between 10 and 20 per 100,000. Ageadjusted incidence in Western, Southeastern, and Eastern Asia and Eastern and Northern Africa ranges between 10 and 20 per 100,000 per year, while mortality is only slightly lower [1]. Screening and diagnostic practice and genetics may contribute to these differences. Lifestyle, quite possibly diet, may also contribute, although components of the diet that contribute to variation in prostate cancer risk have not been elucidated [2]. 
As dietary exposure is ubiquitous, the possibility that diet can reduce prostate cancer risk has attracted a great deal of interest [3]. Indeed, several lines of evidence suggest that diet is related to prostate cancer risk and outcome: epidemiology, international variation, and migration studies suggest that diet is related to prostate cancer risk and course [2]. Studies based on cell lines and animal models also suggest that diet may have important effects. This review will emphasize the larger in vivo, human-based studies that have considered the links between diet and prostate cancer.

A complication of efforts to link dietary practice and prostate cancer risk and mortality among humans is that the prevalence of indolent and asymptomatic prostate cancer is high relative to the incidence of aggressive disease [4]. Thus, to the degree that diet and screening or case finding are associated, the existence of undiagnosed disease in subjects believed to be disease free can confound studies of the linkage between prostate cancer and diet [5]. Because indolent and aggressive prostate cancer may be distinct diseases, with distinct etiologies as well as courses, several diet studies have distinguished aggressive from other prostate cancer [6-13]. Diet may have a greater bearing on the aggressive than on the more indolent form of prostate cancer. Two important chemoprevention studies insisted on pathologic confirmation of cancer status; the Prostate Cancer Prevention Trial of finasteride required an end-of-study biopsy of all participants [5]; and the Reduction by Dutasteride Trial required biopsies at the beginning, middle, and end of treatment [14]. Absent more sensitive and specific imaging technologies, future studies of dietary etiology will require pathologic confirmation of cancer status.

\section{Epidemiology: micronutrients and a major macronutrient}

Dietary epidemiology, evaluating associations between dietary practice and risk within human population samples, is a widely considered means of linking diet with prostate cancer risk [15]. Much of the epidemiologic evidence is observational; its limitation is that causality is difficult to confirm; the most convincing means of establishing that dietary practice has a causal bearing on disease risk in humans is to conduct randomized trials. To date, there have been very few studies of diet and cancer conducted within randomized trials.

Questionnaires have over the past 40 years served as major instruments of dietary epidemiology, with subjects asked about the frequencies and quantities of their consumption of inventories of foods [15]. Investigators have used the data from these inventories to construct indices of nutrient exposure. A limitation of this approach is that the indices are subject to substantial imprecision [16]. The imprecision can cause estimates of the importance of any one nutrient to be misestimated and can make it difficult to disentangle the impact of any one nutrient from those of others. Observed associations can underestimate or overestimate true associations [16]. This problem is lessened in studies in which an exposure or intervention is administered as part of a randomized trial, or in studies in which dietary exposure is assessed by biological markers, such as nutrient levels in blood.

Table 1 summarizes major studies of the micro nutrients and macronutrient that have received the greatest attention in the dietary epidemiology of prostate cancer: carotenoids, fat, vitamin E, vitamin D/calcium, and selenium. 


\section{Carotenoids and retinoids}

An early interpretation of the associations between plant intake and reduced cancer risk was that plants might supply retinoids or carotenoids to protect against cancer at a number of sites $[17,18]$. The data have, however, revealed little association between retinol or retinoids and altered, much less reduced, risk of prostate cancer $[19,20]$. The data regarding carotenoids have proven more encouraging.

Giovannucci's [6] analysis of data from a cohort of almost 48,000 health professionals showed little association between most of the carotenoids and risk. The exception was a strong, negative association of lycopene, the chief carotenoid in tomato products, with risk. The relative risk among those in the top category of lycopene ingestion was diminished by approximately $20 \%$. Although there was an association between tomato intake and risk, the association was stronger for cooked than for raw tomato intake; this could have been caused by cooking's effecting greater absorption of lycopene. A similar result, with a $25 \%$ decrease in risk, was observed by Gann in a plasma-based case-control study nested in a cohort of physicians; this relationship was stronger for aggressive than for more indolent cancer [21]. The lycopene findings are not entirely consistent. A large cohort study of over 58,000 men conducted in the Netherlands; [7] none of the associations of risk with retinol, lycopene, alpha carotene, or beta carotene intake was statistically significant. Among the several antioxidant nutrients considered in blood in a nested case-control study-alpha and beta carotene, total carotene, beta cryptoxanthin, lutein, lycopene, retinal, ascorbic acid—none was associated with decreased risk [22]. In Kolonel's case-control study, carotenoid intake was associated with increased risk [23]. The study revealed no association between carotenoid or retinoid intake and risk. The Alpha Tocopherol, Beta Carotene Trial (ATBC) provided no evidence of an alteration of risk associated with beta carotene supplementation [11]. Andersson et al. [20] was one of many studies to show that retinol intake was associated with increased risk.

Fat

Dietary fat has been blamed for the elevated occurrence of many cancers, including prostate cancer, in the western industrial world [2]. Although there is epidemiologic evidence that dietary fat is associated with increased risk, that evidence is mixed. An early case-control inquiry conducted in Western New York [24] observed a positive association between fat intake and prostate cancer risk. Giovannucci's analysis of the cohort of health professionals revealed no association between total, saturated, or monounsaturated fat and prostate cancer risk [8]. The data revealed no association between risk and the major polyunsaturated fatty acid, linoleic acid. In fact, the relative risk among those in the highest category of monounsaturated fat intake was nearly doubled, to 1.86 [8]. The intake of alpha linolenic acid was associated with risk: major sources of this fatty acid include some vegetable oils and meats. It is important, however, that this fatty acid fraction amounts to a very minor fraction of total fat intake; among those in the top category, alpha linolenic acid constitutes about $1 \%$ of total fat intake [16]. Giovannucci also observed the intake of fat from meats to be associated with increased risk. Gann et al. [25] similarly observed a near doubling of prostate cancer risk in the top alpha linolenic acid category in a plasma-based case-control study nested in a cohort. Hayes's large case-control effort considered dietary determinants 
of prostate cancer among blacks and whites [9]. Among 449 black cases and 543 black controls, risk was nearly doubled among those with the highest category of fat consumption. No such association was observed among the 483 white cases and 658 white controls Hayes evaluated. However, among both blacks and whites, intake of foods high in animal fat was associated with increased risk of advanced prostate cancer [9]. In a nested case-control study within the health professionals' study evaluated by Giovannucci, fish consumption was associated with decreased prostate cancer risk and especially with decreased risk of aggressive cancer [26] (data not shown). But in another nested plasma-based study based on samples provided by a cohort, no association with linoleic acid or marine fatty acids was noted [25] (data not shown).

\section{Vitamin E}

The Alpha Tocopherol, Beta Carotene Trial, conducted in Finland, revealed that those assigned to alpha tocopherol supplementation, $50 \mathrm{mg}$ per day, experienced an unanticipated, $40 \%$ decrease in prostate cancer risk [11]. This protective association was present for clinically significant prostate cancer and for prostate cancer mortality, but not for what was described as latent prostate cancer. However, in the 35,000 man, randomized, Selenium and Vitamin E Chemoprevention Trial (SELECT), no evidence of decreased risk, and suggestive evidence of increased risk, was observed among men assigned to $400 \mathrm{mg}$ per day of vitamin E supplementation [12]. More recent analysis reveals this slight increase in prostate cancer risk to be statistically significant [13].

\section{Vitamin D/calcium}

Giovannucci [27] reviewed the evidence regarding vitamin D in prostate carcinogenesis, concluding that vitamin $\mathrm{D}$ is associated with protection. In light of the close interaction of vitamin D and calcium in intake and metabolism, Giovannucci [10] also evaluated the association between calcium intake and prostate cancer risk in the health professionals' study, observing that elevated calcium intake was associated with an approximately $70 \%$ increase in risk. He suggested that part of the impact of calcium intake could be its impact on vitamin D levels.

\section{Selenium}

Selenium has attracted a great deal of attention as a possible chemopreventive agent. Populations in regions with low soil selenium have elevated cancer risks [28]. A nested case control study based in a large prevention clinical trial, the Carotene and Retinol Efficacy Trial, revealed no association between serum selenium and prostate cancer risk [29]. A large case control study, comparing serum selenium levels of cases and controls [30], suggested a moderate, $30 \%$ decrease in decreased risk with higher selenium levels. Allen's nested casecontrol study in England, with selenium exposure measured by toenail selenium levels, observed no significant or dose-response pattern of association with prostate cancer risk [31]. Allen et al. [32] obtained similar null results in an analysis of the connection between blood selenium and prostate cancer risk in a nested case-control study within a large European cohort. In a nested case-control study, Helzlsouer [33] observed decreased prostate cancer risk with the most elevated levels of selenium. 
The clinical trial of selenium supplementation reported by Duffield-Lillico [28, 34] was initially designed to evaluate the impact of a supplement of selenium $200 \mathrm{mcg}$ per day on basal and squamous cell skin cancer recurrence. The study revealed a statistically significant, 50\% decrease in prostate cancer risk among subjects assigned to selenium supplementation [28, 34]. The most significant decrement in risk was among those with lowest baseline blood selenium levels [34].

The Selenium and Vitamin E chemoprevention Trial (SELECT) was initiated partly in response to mounting interest in selenium as a chemopreventive nutrient [12]. Selenium 200 $\mathrm{mcg} / \mathrm{day}$ in form of selenomethionine was one of the agents administered to the 35,000 average-risk men who participated in the trial. The disappointing result of this high-powered trial was the absence of any evidence that selenium in this form decreased prostate cancer risk [12]. A second trial tested the ability of the same selenium dose and formulation among some 450 men with high grade prostatic intraepithelial neoplasia to prevent the progression of this high-risk condition to prostate cancer [35]. The results were consistent with those of the SELECT: selenium supplementation among HGPIN patients did not prevent the condition from progressing to prostate cancer.

\section{Other possible dietary leads}

Isothiocyanates - compounds found in cruciferous vegetables - have generated interest. Summaries of epidemiologic literature [36-39] indicate that cruciferous vegetables might induce preventive, anticancer activity. The active agents in crucifers are believed to be isothiocyanates; these compounds have a number of functions, including detoxification and antioxidation, which might reduce cancer risk [38]. Cell line-based studies suggest that sulforaphane, an isothiocyanate derived from broccoli, is a powerful inducer of detoxifying enzymes that are often down-regulated in prostate cancer [39]. The induction of phase II enzymes could be partly responsible for the association of intake of broccoli and other cruciferous vegetables with decreased prostate cancer risk [39].

The balance of plant as opposed to animal products in the diet may be important [37]. A small study indicated that a diet emphasizing plant over animal product intake is associated with decreased risk of and a less aggressive course for prostate cancer [3]. The intake of red meat and dairy products, such as milk, cheese, and butter, has been associated with increased risk, while the intake of vegetables in general, but especially of cruciferous vegetables and tomato products, was associated with decreased risk, [6, 24, 40]. On the other hand, Schuurman et al. [41] following a cohort in the Netherlands of nearly 60,000 men found consumption of only some vegetables to be associated with decreased risk.

Schuurman et al. concluded that no substantial alteration of risk is associated with fruit and vegetable consumption. A nested case-control comparison within a multiethnic cohort comprising Japanese, Chinese, European Americans, and African Americans [23] revealed associations of several food components, including soy and other legumes, yellow-orange, and cruciferous vegetables, with decreased risk. This study revealed no association of risk with tomato product or fruit consumption. 


\section{Obesity as a potentially important biomarker}

Although obesity may be affected by individual metabolic factors, obesity as measured by the body mass index may be an important overall biomarker of the excess of energy ingested over energy expended [2]. The overall association of prostate cancer risk to obesity has generally been observed to be weak [42, 43]. What has been more consistently observed is that obese men tend to be diagnosed with more advanced, higher grade disease [43]. In general, obesity is negatively associated with more indolent prostate cancer but positively associated with more aggressive cancer [43, 44]. Obese men are also more likely than lean men to die of prostate cancer [43]. The data on the association of obesity with higher grade disease are not entirely consistent: among members of one cohort, for example, obese men tended to appear with lower-risk disease [45].

The dynamic of the associations between obesity and higher grade disease is not well understood. It could be an artifact, resulting from obesity's making diagnosis more difficult. The association of obesity with elevated risk of higher grade disease could result from obese men having greater blood volume, so that the blood concentration of PSA concentration, used to detect early prostate cancer, is diluted [43]. The digital rectal examination could also be less sensitive for obese than for non-obese men. Causal mechanisms are also possible: obesity could certainly increase the risk only of aggressive disease. The higher estrogen levels of obese men could play a role in their higher risk of aggressive disease. A metabolic syndrome could be possibly linked to obesity and to prostate cancer risk, as abdominal obesity might have different effects than overall obesity [46]. As growth factors may be linked to obesity, investigators have considered growth factors as related to prostate cancer risk. Insulin and linked growth factors are associated with increased risk [47]. A nested case-control study conducted within a large European cohort showed only a weak association with IGF; this association appeared slightly stronger for aggressive prostate cancer [48].

\section{Conclusion}

While there is evidence for a dietary role in prostate cancer, the epidemiologic evidence is frustratingly inconsistent. It is not clear that simple refinements in dietary measurement, such as more elaborate questionnaires and dietary inventories, will clarify the association between diet and prostate cancer or even point the way to more consistent associations. Although biomarkers of nutritional practice may be of use, blood or other readily accessible biomarkers are only available for certain nutrients. Trials, as complex as they may be, may be needed for identifying the importance of diet in prostate cancer risk and course. Fair and Wynder proposed [49] that trials of nutritional modification might help to disentangle the association of diet and prostate carcinogenesis and point the way to nutritional prevention of and therapy for prostate cancer.

A limitation of clinical trials for prostate cancer is that the genesis and emergence of this cancer may take considerable time; the time required for the normal prostate to be transformed to a cancerous one probably spans decades. Thus, trials of preventive interventions for average-risk men need must either be long in duration, based on massive 
samples of subjects, or focused on subjects at elevated risk. The Prostate Cancer Prevention Trial, for example [5], recruited close to 19,000 participants who were followed for 7 years, while the Selenium and Vitamin E Chemoprevention Trial (SELECT) recruited over 35,000 men and monitored them for over 5 years on average [12]. If, however, patients at very high risk of developing clinically significant prostate cancer could be recruited, a trial with smaller numbers of participants could be assembled.

One reasonable group for study would be men with low-grade, low-volume prostate cancer. Such men are increasingly being monitored rather than immediately treated. Although delayed treatment for these patients does not comprise outcome, the 3-year likelihood of aggressive, clinically significant disease development among such men has been estimated to be as high as 30\% [50-54]. Parsons and colleague have initiated a randomized clinical trial of diet change for men with early-stage prostate cancer: the Men's Eating and Living Study (MEAL). The justification for this trial is the need for stronger evidence regarding dietary effects. Although the common, indolent form of prostate cancer may be distinct from the aggressive form that is life-threatening, the indolent form may over time, due to such environmental influences as diet, evolve to the aggressive form. The hypothesis of the MEAL study is that a change to a diet that emphasizes intake of vegetables and fruits and that discourages the intake of animal products will slow the progression of the indolent to the aggressive form of prostate cancer. Prostate cancer patients can readily adopt a diet that emphasizes vegetables and fruits [55-57].

The MEAL study, now open through the National Cancer Institute cooperative groups and Clinical Trials Support Unit, will seek to enroll 460 low-grade, low-volume prostate cancer patients. Subjects, on trial for 2 years, will be monitored by PSA every 3 months and receive a repeat biopsy at one and at 2 years on study. The outcome of the trial will be progression as marked by an increase in the Gleason grade of the cancer, an increase in the PSA, a decrease in the doubling time of the PSA, or an increase in the volume of the cancer. This trial can be accessed through the Clinical Trial Support Unit of the National Cancer Institute of the US, or by contacting the Alliance for Clinical Trials in Oncology Network or the Southwest Oncology Group.

In spite of the considerable effort expended to date, including the investigation of such dimensions of the diet as total energy, nutrients, vegetables, fruits, meats, fish, dairy products, and whole grains, findings have been weak and inconsistent. One of the strongest associations observed is between body mass index, a biomarker that largely reflects an excess of energy intake over energy expenditure, and risk of aggressive cancer. An ongoing trial will test the modest epidemiologic evidence that a diet that emphasizes vegetable and fruit consumption may impart a slight advantage. Whether the modesty of the advantage observed to date stems more from the unimportance of the diet or from difficulties in measuring and quantifying the diet is not clear. Clinical trials may help to identify more clearly whether diet modification might alter the risk and course of prostate cancer. A trial now open will consider whether diet change affects the progression of low-grade, small volume prostate cancer. 


\section{Acknowledgments}

Manuscript supported by National Cancer Institute grant R01-CA132951, "Diet change among prostate cancer patients under expectant management."

\section{References}

1. Globocan. Prostate cancer incidence and mortality world-wide in 2008 summary. 2008 http:// globocan.iarc.fr/factsheets/cancers/prostate.asp.

2. World Cancer Research Fund/American Institute for Cancer Research. Food, nutrition, physical activity, and the prevention of cancer: a global perspective. Washington, DC: American Institute for Cancer Research; 2007.

3. Sonn GA, Aronson WJ, Litwin MS. Impact of diet on prostate cancer: a review. Prostate Cancer and Prostatic Dis. 2005; 8:304-310.

4. Breslow N, Chan CW, Dhom G, Drury RAB, Franks LM, Gellei B, Lee YS, Lundberg S, Sparke B, Sternby NH, Tulinius H. Latent carcinoma of prostate at autopsy in seven areas collaborative study organized by the international agency for research on cancer, Lyons, France. Int J Cancer. 1977; 20:680-688. [PubMed: 924691]

5. Thompson IM, Goodman PJ, Tangen CM, Lucia MS, Miller GJ, Ford LG, Lieber MM, Cespedes RD, Atkins JN, Lippman SM, Carlin SM, Ryan A, Szczepanek CM, et al. The influence of finasteride on the development of prostate cancer. N Engl J Med. 2003; 349:215-224. [PubMed: 12824459]

6. Giovannucci E, Ascherio A, Rimm EB, Stampfer MJ, Colditz GA, Willett WC. Intake of carotenoids and retinol in relation to risk of prostate cancer. J Natl Cancer Inst. 1995; 87:17671776. [PubMed: 7473833]

7. Schuurman AG, Goldbohm RA, Brants HA, Van Den Brandt PA. A prospective cohort study on intake of retinol, vitamins $\mathrm{C}$ and $\mathrm{E}$ carotenoids and prostate cancer risk (Netherlands). Cancer Causes Control. 2002; 13:573-582. [PubMed: 12195647]

8. Giovannucci E, Rimm EB, Colditz GA, Stampfer MJ, Ascherio A, Chute CC, Willett WC. A prospective study of dietary fat and risk of prostate cancer. J Natl Cancer Inst. 1993; 85:1571-1579. [PubMed: 8105097]

9. Hayes RB, Ziegler RG, Gridley G, Swanson C, Greenberg RS, Swanson GM, Schoenberg JB, Silverman DT, Brown LM, Pottern LM, Liff J, Schwartz AG, et al. Dietary factors and risks for prostate cancer among blacks and whites in the United States. Cancer Epidemiol Biomark Prevent. 1999; 8:25-34.

10. Giovannucci E, Liu Y, Stampfer MJ, Willett WC. A Prospective Study of Calcium Intake and Incident and Fatal Prostate Cancer. Cancer Epidemiol Biomark Prevent. 2006; 15:203-210.

11. Heinonen OP, Albanes D, Virtamo J, Taylor PR, Huttunen JK, Hartman AM, Haapakoski J, Malila N, Rautalahti M, Ripatti S, Maenpaa H, Teerenhovi L, Koss L, Virolainen M, Edwards BK.

Prostate cancer and supplementation with a-tocopherol and B-carotene: incidence and mortality in a controlled trial. J Natl Cancer Inst. 1998; 90:440-446. [PubMed: 9521168]

12. Lippman SM, Klein EA, Goodman PJ, Lucia MS, Thompson IM, Ford LG, Parnes HL, Minasian LM, Gaziano JM, Hartline JA, Parsons JK, Bearden JD, Crawford ED, Goodman GE, Claudio J, Winquist E, Cook ED, Karp DD, Walther P, Lieber MM, Kristal AR, Darke AK, Arnold KB, Ganz PA, Santella RM, Albanes D, Taylor PR, Probstfield JL, Jagpal TJ, Crowley JJ, Meyskens FL, Baker LH, Coltman CA. Effect of selenium and vitamin E on risk of prostate cancer and other cancers The selenium and vitamin E cancer prevention trial (SELECT). J Am Med Assoc. 2009; 301:E1-E13.

13. Klein EA, Thompson IM, Tangen CM, Crowley JJ, Lucia MS, Goodman PJ, Minasian LM, Ford LG, Parnes HL, Gaziano JM, Karp DD, Lieber MM, Walther PJ, Klotz L, Parsons JK, Chin JL, Darke AK, Lippman SM, Goodman GE, Meyskens FL, Baker LH. Vitamin E and the risk of prostate cancer The selenium and vitamin E cancer prevention trial (SELECT). J Am Med Assoc. 2011; 306:1549-1556.

14. Andriole GL, Bostwick DG, Brawley OW, Gomella LG, Marberger M, Montorsi F, Pettaway CA, Tammela TL, Teloken C, Tindall DJ, Somerville MC, Wilson TH, Fowler IL, Rittmaster RS. For 
the Reduce Study Group. Effect of dutasteride on the risk of prostate cancer. N Engl J Med. 2010; 362:1192-1202. [PubMed: 20357281]

15. Willett, W. Nutritional epidemiology. Oxford: Oxford University Press; 1998.

16. Marshall JR, Chen Z. Diet and health risk: risk patterns and disease-specific associations. Am J Clin Nutr. 1999; 69:1351S-1356S. [PubMed: 10359236]

17. Graham S. Diet and Cancer. Am J Epidemiol. 1980; 112:247-252. [PubMed: 6251718]

18. Graham S. Epidemiolgic studies of diet and cancer (42420). Proc Soc Exp Biol Med. 1986; 183:281-286. [PubMed: 3025884]

19. Kolonel LN, Hinds MW, Nomura AMY, Hankin JH, Lee J. Relationship of dietary vitamin A and ascorbic acid intake to the risk for cancers of the lung, bladder, and prostate in Hawaii. Monogr Natl Cancer Inst. 1985; 69:137-142.

20. Andersson SO, Wolk A, Bergstrom R, Giovannucci E, Lindgren C, Baron J, Adami HO. Energy, nutrient intake and prostate cancer risk: a population-based case-control study in Sweden. Int J Cancer. 1996; 68:716-722. [PubMed: 8980172]

21. Gann PH, Ma J, Giovannucci E, Willet WC, Sacks FM, Hennekens CH, Stampfer MJ. Lower prostate cancer risk in men with elevated plasma lycopene levels: results of a prospective analysis. Cancer Res. 1999; 59:1225-1230. [PubMed: 10096552]

22. Huang HY, Alberg AJ, Norkus EP, Hoffman SC, Comstock GW, Helzlsouer KJ. Prospective study of antioxidant micronutrients in the blood and the risk of developing prostate cancer. Am J Epidemiol. 2003; 157:335-344. [PubMed: 12578804]

23. Kolonel LN, Hankin JH, Whittemore AS, Wu AH, Gallagher RP, Wilkens LR, John EM, Howe GR, Dreon DM, West DW, Paffenbarger RS. Vegetables, fruits, legumes and prostate cancer: a multiethnic case-control study. Cancer Epidemiol Biomark Prevent. 2000; 9:795-804.

24. Graham S, Haughey B, Marshall J, Priore R, Byers T, Rzepka T, Mettlin C, Pontes JE. Diet in the epidemiology of carcinoma of the prostate gland. J Natl Cancer Inst. 1983; 70:687-692. [PubMed: 6572757]

25. Gann PH, Hennekens CH, Sacks FM, Grodstein F, Giovannucci E, Stampfer MJ. Prospective study of plasma fatty acids and risk of prostate cancer. J Natl Cancer Inst. 1994; 86:281-286. [PubMed: 8158682]

26. Augustsson K, Michaud DS, Rimm EB, Leitzmann MF, Stampfer MJ, Willet WC, Giovannucci E. A prospective study of intake of fish and marine fatty acids and prostate cancer. Cancer Epidemiol Biomark Prevent. 2003; 12:64-67.

27. Giovannucci E. The epidemiology of vitamin D and cancer incidence and mortality: a review (United States). Cancer Causes Control. 2005; 16:83-95. [PubMed: 15868450]

28. Clark LC, Combs GF, Turnbull BW, Slate EH, Chalker DK, Chow J, Davis LS, Glover RA, Graham GF, Gross EG, Krongrad A, Lesher JL, Park HK, Sanders BB, Smith CL, Taylor JR. For the Nutritional Prevention of Cancer Study Group. Effects of selenium supplementation for cancer prevention in patients with carcinoma of the skin a randomized controlled trial. J Am Med Assoc. 1996; 276:1957-1963.

29. Goodman GE, Schaffer S, Bankson DD, Hughes MP, Omen GS. The Carotene Retional Efficacy Trial (CARET) Co-Investigators. Predictors of serum selenium in cigarette smokers and the lack of association with lung and prostate cancer risk. Cancer Epidemiol Biomark Prevent. 2001; 10:1069-1076.

30. Vogt TM, Ziegler RG, Graubard BI, Swanson CA, Greenberg RS, Schoenberg JB, Swanson GM, Hayes RB, Mayne ST. Serum selenium and risk of prostate cancer in U.S. blacks and whites. Int J Cancer. 2003; 103:664-670. [PubMed: 12494476]

31. Allen NE, Morris JS, Ngwenyama RA, Key TJ. A case-control study of selenium in nails and prostate cancer risk in British men. Br J Cancer. 2004; 90:1392-1396. [PubMed: 15054461]

32. Allen NE, Appleby PN, Roddam AW, Tjonneland A, Johnsen NF, Overvad K, Boeing H, Weikert S, Kaaks R, Linseisen J, Trichopoulou A, Misirli G, Trichopoulos D, Sacerdote C, Grioni S, Palli D, Tumino R, Bueno-de-Mesquita HB, Kiemeney LA, Barricarte A, Larranaga N, Sanchez MJ, Agudo A, Tormo MJ, Rodriguez L, Stattin P, Hallmans G, Bingham S, Khaw KT, Slimani N, Rinaldi S, Boffetta P, Riboli E, Key TJ. Plasma selenium concentration and prostate cancer risk: 
results from the European Prospective Investigation into cancer and nutrition (EPIC)1-3. Am J Clin Nutr. 2008; 88:1567-1575. [PubMed: 19064517]

33. Helzlsouer KJ, Huang HY, Alberg AJ, Hoffman S, Burke A, Norkus EP, Morris JS, Comstock GW. Association between a-tocopherol, y-tocopherol, selenium, and subsequent prostate cancer. J Natl Cancer Inst. 2000; 92:2018-2023. [PubMed: 11121464]

34. Duffield-Lillico AJ, Dalkin BL, Reid ME, Turnbull BW, Slate EH, Jacobs ET, Marshall JR, Clark LC. Selenium supplementation, baseline plasma selenium status and incidence of prostate cancer: an analysis of the complete treatment period of the nutritional prevention of cancer trial. BJU Int. 2003; 91:608-612. [PubMed: 12699469]

35. Marshall JR, Tangen CM, Sakr WA, Wood DP, Berry DL, Klein EA, Lippman SM, Parnes HL, Alberts DS, Jarrard DF, Lee WR, Gaziano JM, Crawford ED, Ely B, Ray M, Davis W, Minasian LM, Thompson IM. Phase III Trial of Selenium to Prevent Prostate Cancer in Men with Highgrade prostatic intraepithelial neoplasia: SWOG S9917. Cancer Prevent Res. 2011

36. Kristal AR, Stanford JL. Cruciferous vegetables and prostate cancer risk: confounding by PSA screening. Cancer Epidemiol Biomark Prevent. 2004; 13:1265.

37. Chan JM, Gann PH, Giovannucci EL. Role of diet in prostate cancer development and progression. J Clin Oncol. 2005; 23:8152-8160. [PubMed: 16278466]

38. Zhang Y, Munday R, Jobson HE, Munday CM, Lister C, Wilson P, et al. Induction of GST and NQO1 in cultured bladder cells and in the urinary bladder of rats by an extract of broccoli (Brassica Italica) sprouts. J Agric Food Chem. 2006; 54:9370-9376. [PubMed: 17147420]

39. Brooks JD, Paton VG, Vidanes G. Potent induction of phase II enzymes in human prostate cells by sulforaphane. CEBP. 2001; 10:949-954.

40. Kristal AR, Cohen JH, Qu P, Stanford JL. Associations of energy, fat, calcium, and vitamin D with prostate cancer risk. Cancer Epidemiol Biomark Prevent. 2002; 11:719-725.

41. Schuurman AG, Goldbohm RA, Dorant E, Van Den Brandt PA. Vegetable and fruit consumption and prostate cancer risk: a cohort study in the Netherlands. Cancer Epidemiol Biomark Prevent. 1998; 7:673-680.

42. Gronberg H, Damber L, Damber JE. Total food consumption and body mass index in relation to prostate cancer risk: a case-control study in Sweden with prospectively collected exposure data. J Urol. 1996; 155:969-974. [PubMed: 8583620]

43. Freedland SJ, Platz EA. Obesity and prostate cancer: making sense out of apparently conflicting data. Epidemiol Rev. 2007; 29:88-97. [PubMed: 17478439]

44. Gong Z, Neuhouser ML, Goodman PJ, Albanes D, Chi C, Hsing AW, Lippman SM, Platz EA, Pollak MN, Thompson IM, Kristal AR. Obesity, diabetes, and risk of prostate cancer: results from the Prostate Cancer Prevention Trial. Cancer Epidemiol Biomark Prevent. 2006; 15:1977-1983.

45. Kane CJ, Bassett WW, Sadetsky N, Silva S, Wallace K, Pasta DJ, Cooperberg MR, Chan JM, Carroll PR. Obesity and prostate cancer clinical risk factors at presentation: data from CaPsure. J Urol. 2005; 173:732-736. [PubMed: 15711258]

46. Hsing AW, Sakoda LC, Chua SC. Obesity, metabolic syndrome, and prostate cancer. Am J Clin Nutr. 2007; 86(supplement):843S-857S.

47. Chen C, Freeman R, Voigt LF, Fitzpatrick A, Plymate SR, Weiss NS. Prostate cancer risk in relation to selected genetic polymorphisms in insulin-like growth factor-1, insulin-like growth factor binding protein-3, and insulin-like growth factor-1 receptor. Cancer Epidemiol Biomark Prevent. 2006; 15:2461-2466.

48. Allen NE, Key TJ, Appleby PN, Travis RC, Roddam AW, Rinaldi S, Egevad L, Rohrmann S, Linseisen J, Pischon T, Boeing H, Johnsen NF, Tjonneland A, Gronbaek H, Overvad K, Kiemeney L, Bueno-de-Mesquita HB, Bingham S, Khaw KT, Tumino R, Berrino F, Mattiello A, Sacerdote C, Palli D, Quiros JR, Ardanaz E, Navarro C, Larranaga N, Gonzalez C, Sanchez MJ, Trichopoulou A, Travezea C, Trichopoulos D, Jenab M, Ferrari P, Riboli E, Kaaks R. Serum insulin-like growth factor (IGF)-I and IGF-binding protein-3 concentrations and prostate cancer risk: results from the European prospective investigation into cancer and nutrition. Cancer Epidemiol Biomark Prevent. 2007; 16:1121-1127.

49. Fair WR, Wynder EL. Editorial: prostate cancer-nutrition adjunct therapy. J Urol. 1996; 156:1364-1365. [PubMed: 8808872] 
50. Klotz L. Active surveillance for prostate cancer: for whom? JCO. 2005; 23:8165-8169.

51. Klotz L, Zhang L, Adam L, Nam R, Mamedov A, Loblaw A. Clinical results of long-term followup of a large, active surveillance cohort with localized prostate cancer. J Clin Oncol. 2010; 28:126-131. [PubMed: 19917860]

52. Khan MA, Carter HB, Epstein JI, et al. Cancer prostate specific antigen derivatives and pathological parameters predict significant change in expectant management criteria for prostate cancer? J Urol. 2003; 170:2274-2278. [PubMed: 14634395]

53. Warlick C, Trock BJ, Landis P, Epstein JI, Carter HB. Delayed versus immediate surgical intervention and prostate cancer outcome. J Natl Cancer Inst. 2006; 98:355-357. [PubMed: 16507832]

54. Carter HB, Kettermann A, Warlick C, Metter EJ, Landis P, Walsh PC, Epstein JI. Expectant management of prostate cancer with curative intent: an update of the Johns Hopkins experience. $J$ Urol. 2007; 178:2359-2365. [PubMed: 17936806]

55. Parsons JK, Newman V, Mohler JL, Pierce JP, Paskett E, Marshall J. The men's eating and living (MEAL) study: a cancer and leukemia group B pilot trial of dietary intervention for the treatment of prostate cancer. Urology. 2008; 72:633-637. [PubMed: 18280560]

56. Parsons JK, Newman VA, Mohler JL, Pierce JP, Flatt S, Marshall J. Dietary modification in patients with prostate cancer on active surveillance: a randomized, multicentre feasibility study. British J Urol Int. 2008; 101:1227-1231.

57. Parsons JK, Newman V, Mohler J, Pierce JP, Flatt SW, Messner K, Marshall JR. Dietary intervention after definitive therapy are localized prostate cancer: results from a pilot study. Can J Urol. 2009; 16:4648-4654. [PubMed: 19497171] 
Table 1

Nutrients/diet components and prostate cancer risk: relative risk of highest exposure category

\begin{tabular}{|c|c|c|c|c|}
\hline Author, reference & Study design & Exposure measure & Nutrient/component & Relative risk $(P)^{*}$ \\
\hline \multicolumn{5}{|l|}{ Carotenoids } \\
\hline \multirow[t]{4}{*}{ Gann et al. [21] } & Nested & Plasma & a Carotene & $77(/ 09)$ \\
\hline & $\mathrm{Ca} / \mathrm{Co}$ & & Lycopene & $75(12)$ \\
\hline & 578 cases & & Luteine & $1.10(.63)$ \\
\hline & (294 controls) & & B Cryptoxanthin & $80(.29)$ \\
\hline \multirow[t]{5}{*}{ Giovannucci [27] } & Prospective 47,894 & Questionnaire & a Carotene & $1.09(.77)$ \\
\hline & & & $\beta$ Carotene & $1.05(.70)$ \\
\hline & & & $\beta$ Cryptoxanthin & $.94(.76)$ \\
\hline & & & Lycopene & $.79(.04)$ \\
\hline & & & Luteine & $1.10(.34)$ \\
\hline Hayes et al. [9] & $\mathrm{Ca} / \mathrm{Co}$ & Questionnaire & & \\
\hline \multirow[t]{2}{*}{ Blacks } & 449 cases & & Lycopene & $1.0(.26)$ \\
\hline & 543 controls & & & \\
\hline \multirow[t]{2}{*}{ Whites } & 483 cases & & Lycopene $^{a}$ & $0.9(.17)$ \\
\hline & 658 controls & & & \\
\hline Heinonen et al. [11] & Randomized trial 29,133 & Supplement & $\beta$ Carotene & $1.23(>.05)^{b}$ \\
\hline Huang et al. [22] & Nested & Plasma & a Carotene & $.93(.61)$ \\
\hline \multirow[t]{5}{*}{ CLUEJ } & Case control & & $\beta$ Carotene & $.94(.59)$ \\
\hline & 182 cases & & Total carotene & $.90(.57)$ \\
\hline & 364 controls & & $\beta$ Cryptoxanthin & $1.25(.30)$ \\
\hline & & & Lycopene & $.83(.72)$ \\
\hline & & & & $1.26(.30)$ \\
\hline \multirow[t]{6}{*}{ CLUEII } & Case control & & a Carotene & $1.11(.98)$ \\
\hline & 142 cases & & $\beta$ Carotene & $1.47(.60)$ \\
\hline & 284 controls & & Total carotene & $1.06(.65)$ \\
\hline & & & $\beta$ Cryptoxanthin & $.90(.82)$ \\
\hline & & & Lycopene & $.79(.49)$ \\
\hline & & & Luteine & $.68(.07)$ \\
\hline \multicolumn{5}{|l|}{ Dietary fat } \\
\hline \multirow[t]{7}{*}{ Gann et al. [25] } & Nested $\mathrm{Ca} / \mathrm{Co}$ & Plasma & Palmitic acid & $.90(.78)$ \\
\hline & 120 cases & & Stearic acid & $.35(.07)$ \\
\hline & 120 controls & & Oleic acid & $1.50(.47)$ \\
\hline & & & Linoleic acid & $.62(.24)$ \\
\hline & & & a Linoleic acid & $2.14(.03)$ \\
\hline & & & Arachidonic acid & $1.36(.76)$ \\
\hline & & & Elcosapentaenoic acid & $.87(.81)$ \\
\hline \multirow[t]{3}{*}{ Giovannucci et al. [8] } & Prospective 51,529 & Questionnaire & Total fat & $1.32(.32)$ \\
\hline & & & Saturated fat & $.84(.93)$ \\
\hline & & & Monounsaturated fat & $1.86(.93)$ \\
\hline
\end{tabular}

World J Urol. Author manuscript; available in PMC 2015 January 22. 


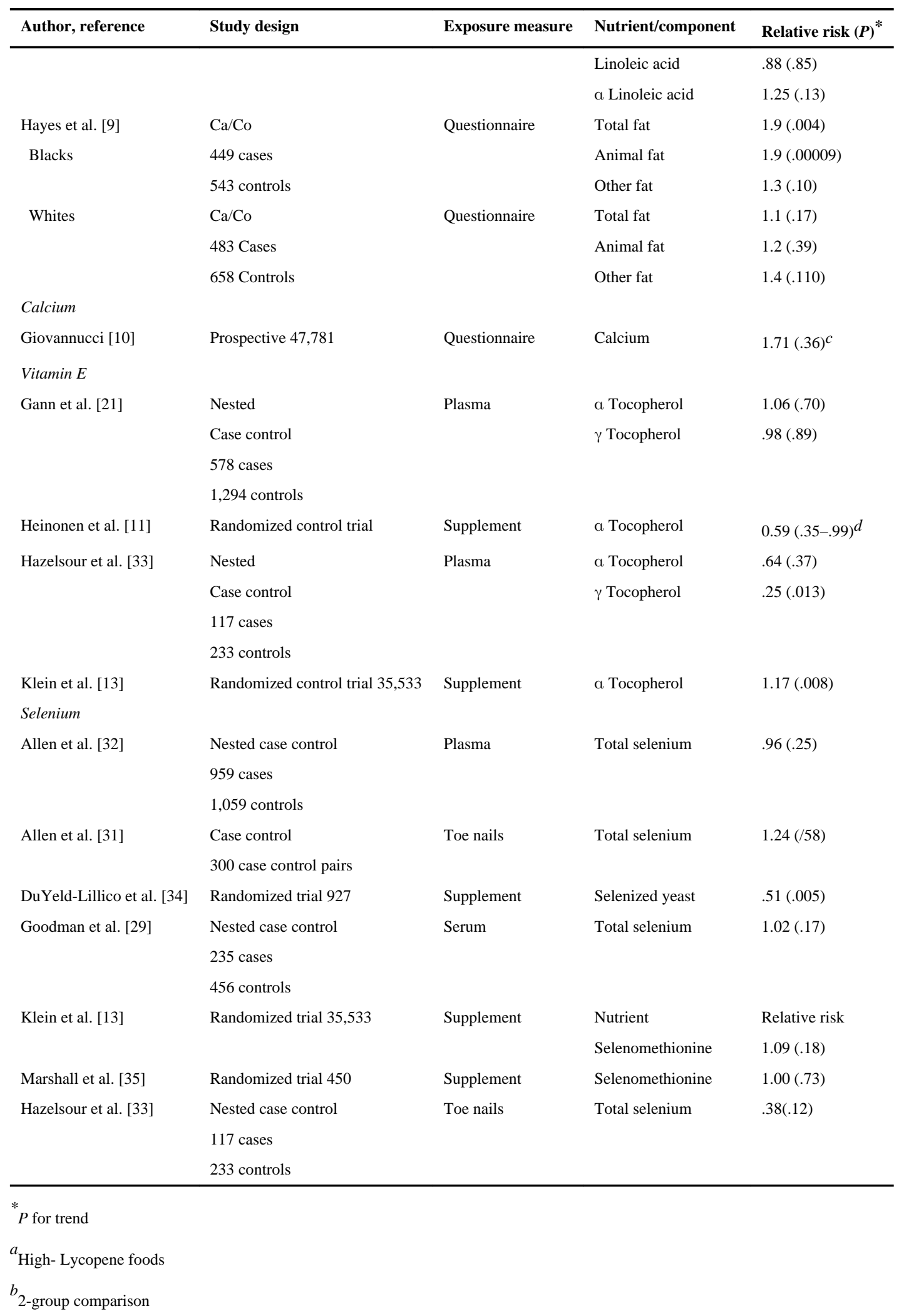


${ }^{c}$ Excluding stage A1

$d_{95 \% \text { Confidence interval }}$ 